\author{
한국 탄도만 낙지자원의 이용과 관리 \\ 오택윤 ${ }^{*} \cdot$ 김주일 $^{1} \cdot$ 서영일 $^{2} \cdot$ 이선길 $^{2} \cdot$ 최문성 $^{2} \cdot$ 주현 $^{2} \cdot$ 정순범 ${ }^{3}$ \\ 국립수산과학원 자원관리과* , ${ }^{1}$ 국립수산과학원 남동해수산연구소, \\ ${ }^{2}$ 국립수산과학원 남서해수산연구소 자원환경과, ${ }^{3}$ 전남대학교 해양기술학부
}

\title{
A utilization and management of common octopus (Octopus minor) resources in the Tando bay on the southwest coast of Korea
}

\author{
Taeg-Yun OH *, Joo-Il KIM, Young-Il SeO, Sun-Kil LeE, Mun-Seung CHO, Hyun Joo \\ and Sun-Beom JEONG \\ Fisheries Resources Management Division, National Fisheries Research Institute, \\ NFRDI, Busan 619-705, Korea \\ ${ }^{1}$ Southeast Sea Fisheries Research Institute, NFRDI, Tongyeong 650-7373, Korea \\ ${ }^{2}$ Fisheries Resource and Environment Division, Southwest Sea Fisheries Research Institute, \\ NFRDI, Yeosu 556-823, Korea \\ ${ }^{3}$ Division of Marine Technology, Chonnam National University, Yeosu, Chonnam 550-749, Korea
}

This study is to contribute to income growth of fishermen by the common octopus fishery characterized in the Tando Bay on the southwest coast of Korea. This area is engaged in Longline fishing (301 persons), Shovel fishing (196 persons), Trap fishing (14 persons) and Torch light fishing (40 persons) in 2008. Population who is joined in the spring becomes main fishery target population of longline fishery in the fall because entering fishing ground in August, and is joined in the fall becomes main fishery target population of longline fishery in the spring because entering fishing ground in December. Average size of common octopus examined by longline $6.26 \mathrm{~cm}, 5.82 \mathrm{~cm}$ for Shovel fishing, $8.09 \mathrm{~cm}$ for trap, and expressed big difference by fishery. It needs necessary various kinds of Octopus resource management actions and methods in continuous use. Specially, Fishing force increased by fishing automation system, so the reduction of fishing force is needed to increased by fishing force. Government support and fishermen's self-conscious of resource management is needed.

Keywords: Tando Bay, Octopus minor, common octopus, Longline fishing

*Corresponding author: tyoh@nfrdi.go.kr.kr, Tel: 82-51-720-2295, Fax: 82-51-720-2277 


\section{서 론}

낙지 (Octopus minor)는 주꾸미 (O. ocellatus), 문어 (O. vulgaris), 문어 (O. dofleini)와 함께 두족 강 (Cephalopoda), 문어목 (Octopoda), 문어과 (Octopodidae)에 속하는 연체동물서 한국, 일본, 중국 등 서부 태평양 연안 역에 분포한다 (Roper et al., 1984). 특히 우리나라 연안에서는 거문도 이북의 조간대에서 수심 $150 \mathrm{~m}$ 사이의 바위 톱과 내만의 개펄지역에 주로 분포하며 연승과 통발, 도수 등으로 어획하는 서해 남부와 남해 서부 연 안어업인 중요한 소득 대상 종이다. 이와 같이 연안어업인의 주요 어획 대상 종임에도 불구하 고 현재까지는 생태학적 연구로서 Moon (1989) 은 경기만 낙지의 형태 및 성장에 대하여, Chang and Kim (2003)은 낙지의 습성 및 행동 특성에 대하여, Jung and Kim (2001)의 낙지 연승어장의 해황과 어획변동에 대한 연구, Go (2005)는 낙지 의 어구에 대한 행동 특성에 대하여, Kim et al. (2004)은 남해안 낙지의 성장과 산란에 대하여 부분적으로 연구가 시도되고 있는 실정이고, 자 원을 이용 관리하는 분야의 연구는 전무한 설정 이다. 또한 국외에서도 생태학적인 연구 결과로 서 Octopus vulgaris의 자원 성상 (Tanaka, 1958), Octopus mimus 의 성장 (Cortez et al., 1999), Dosidicus gigas의 연령과 성장 및 개체군 구조 (Arguelles et al., 2001), Octopus vulgaris의 번식 (Hernandez-Garcia et al., 2002) 등에 관한 연구보 고가 있다.

우리나라의 낙지 어획량은 1993년 14,000톤으 로 최고치를 기록한 후 어획량이 점차 감소하여 2002년 5,297톤까지 현저하게 감소한 후 2008년 7,881 톤까지 어획량이 점차 증가하고 있는 종이 다 (MIFAFF, 2009). 이와 같은 낙지는 전남지역 낙지 생산량이 전국의 약 $70-80 \%$ 를 차지함으 로 Jung and Kim (2001)은 서해 남부해역의 갯벌 에 서식하는 낙지 자원관리의 중요성 강조하고 있다. 서해 남부해역 니질 함량이 풍부한 갯벌에 서 서식하는 일명 뺄낙지 또는 세발낙지는 사니
질이나 돌이나 모래에 서식하는 돌낙지 또는 꽃 낙지 보다 선호하는 수산물로서 고가로 판매되 며, 일명 세발낙지로 불린다. 이와 같이 중요한 연안 자원인 세발낙지의 주산지는 전남 영암군, 무안군, 신안군 등지였으나, 영암군은 연안 매립 으로 낙지 생산이 전무한 설정이고, 무안군과 신 안군에서는 과거에 비해 생산량이 많이 감소되 었다. 이와 같이 최근에 갯벌에서 낙지 어획량이 감소함에 따라 자원관리의 필요성이 대두되고 있다. 따라서 본 연구에서는 서해 남부해역에 위 치한 탄도만 내 낙지어업의 특성을 조사 분석하 여, 지역 연안 어업인이 지속적이고 안정적으로 어업을 유지하여 어가 소득에 기여할 수 있는 방 안을 모색하고자 한다.

\section{조사방법}

전라남도 무안군에 위치한 탄도만은 Fig. 1에 나타낸 것과 같이 육지와 섬으로 둘러싸인 내만 으로 만의 중심부에 탄도가 위치해 있다. 탄도만 은 대부분의 지역이 개펄과 개펄지역의 수로로 이루어져 있어, 썰물 때에는 수로를 제외하고는 물이 빠져 개펄이 공기 중에 드러나고, 밀물 때 에는 물에 잠기는 해역이다.

탄도만 내의 낙지어업 현황을 파악하기 위하 여 낙지어업에 종사하는 어가수와 조업 어구와 방법에 따라 구분하여 연승, 도수, 횟불, 통발어 업에 대하여 조사를 실시하였다. 탄도만 내에서 조업하는 어업인수는 각 어촌계장을 대상으로 설문조사를 실시하였으며, 낙지를 어획하는 어 구에 대한조사는 실물에 대하여 현장조사를 실 시하였고, 어법에 대해서는 직접체험 또는 승선 조사를 실시하였다.

탄도만 내의 낙지 어업별 어획량 조사는 연승 으로 조업하는 35 곳의 표본 어가, 도수어업으로 어획하는 15 곳의 표본어가와 횃불어업으로 조 업하는 12 곳의 표본 어가 및 통발어업 조업선 1 척을 표본어가로 선정하여 조업 시 매일 작성한 조업일지 기록에서 어업 표본 어획량을 조사하 


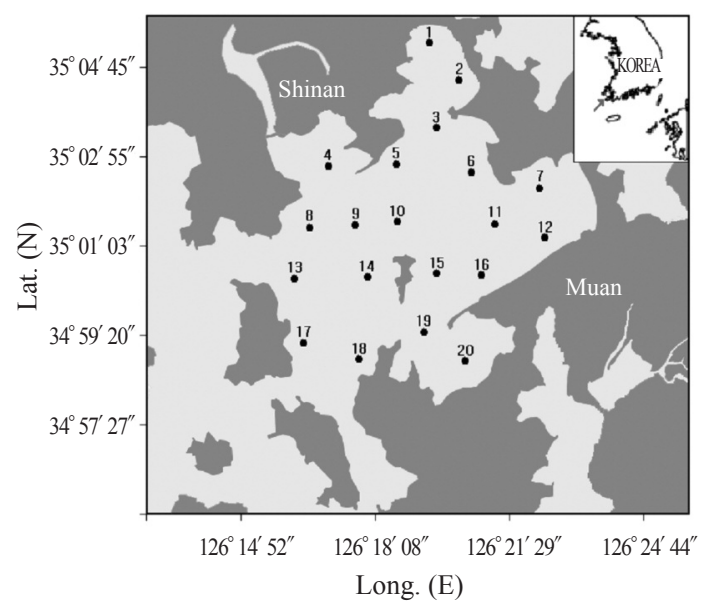

Fig. 1. The research area of Octopus minor in Tando bay, Korea.

여, 이를 어업별로 전체 어업수로 환산하여 월별 어획량을 추정하였다. 탄도만 낙지의 자원생물 학적 특성치를 파악하기 위하여 20개 어획정점 (Fig. 1) 에서 매월 30 분씩 연승으로 어획시험을 실시하여 시험에서 어획된 낙지를 사용하여 생 물학적 특성치 조사를 실시하였고, 연승에서 어 획된 어획량이 미미한 하계와 동계에는 도수어 업과 횃불어업에서 어획된 낙지로 생물학조사 를 실시하였다.

\section{결과 및 고찰}

\section{탄도만 낙지어업 현황}

탄도만 낙지어업 이용현황 조사

탄도만 내에서 낙지 자원을 이용하는 어촌계 별 업종별 어업인 수는 14 개 어촌계에서 751 명 이며, 어촌계별로는 곡지, 용유, 송현, 성동 어촌 계 순으로 계원수가 많았다. 어업별 어업인수에 서는 만조시에는 수심이 매우 낮고, 간조시에는 펄인 지역에서 야간에 조업을 하는 연승어업인 수는 301 명, 간조시 나타나는 펄 지역에서 주간 에 조업하는 도수어업인수는 196명, 만조시 해 안가에서 조업하는 햇불어업인수는 40 명 그리 고 도수어업을 겸업하는 어업인수는 54명 이었 다. 그 밖에 개웅지역에서 4-6월에 간조시에 조
업하는 통발어업에 종사하는 어업인수는 14 명 정도로 조사되었다.

\section{어구 및 어법 현황}

탄도만 내에서 연안어업인 조업에 이용되는 어구는 아래 Fig. 2와 같이 연승, 도수, 횃불, 통 발을 사용하고 있다 (NFRDI, 2008). 연승은 살아 있는 칠게 (Macrophthalmus japonicus)를 Fig. 2의 $\mathrm{E}$ 와 같은 낚시 바늘 없는 얇은 판에 Fig. 2의 F와 같이 고무줄을 이용하여 묶고, 미끼인 칠게가 달 린 120 개 내외의 가지줄을 부착하며, 양쪽에 부 자와 침자를 연결한 길이 $150-200 \mathrm{~m}$ 내외의 어 구이다. 조업 시에는 우선 한쪽의 스티로폼 부자 와 멍을 내린 후 길게 일직선으로 투승을 하고, 끝 쪽의 멍을 내린 후 스티로폼 부자 옆의 고리 를 선미에 걸고, 미속으로 투승방향과 직각 방향 으로 2-3분 정도 주낙을 예인한다. 양승시에는 스티로폼 부자를 풀어 수면에 띄우고 모릿줄을 들어 올리면서 양승을 시작한다. 초창기의 낙지 연승어업은 연승어구 양쪽 끝을 나무막대기로 고정한 상태에서 무동력 조업선이 양쪽 끝을 반 복하여 왕복하면서 낚시에 붙은 낙지를 어획하 는 형태로 조업하였지만, 그 후 어구어법이 발전 하여 현재와 같이 양쪽 끝을 고정하지 않고 양쪽 에 추를 사용하여 한쪽 끝은 추로 어구를 고정하 고 다른 한쪽 끝을 조업선에 고정하여 아주 느린 속도로 이동하면서 어장을 소해하여 낙지가 미 끼에 접촉할 수 있는 더 많은 기회를 가질 수 있 도록 어획강도를 증가시키고, 2009년 부터 연승 기가 개발되면서 2 인 조업체계에서 1 인 조업이 가능하도록 되었다.

도수어업은 Fig. 2의 B와 같은 어구를 이용하 여 주간 썰물 때 나타나는 갯벌에서 도보로 이동 하면서 낙지가 갯벌에 잠입한 숨 구명을 찾아 어 구인 가래 (갯벌 전용 삽)를 이용하여 펄을 파내 고 그 속에 있는 낙지를 어획하는 어업이며, 횃 불어업은 주로 겨울철 밀물 때에 막대기 끝에 솜 뭉치를 부착하여 솜뭉치에 석유와 같은 인화물 


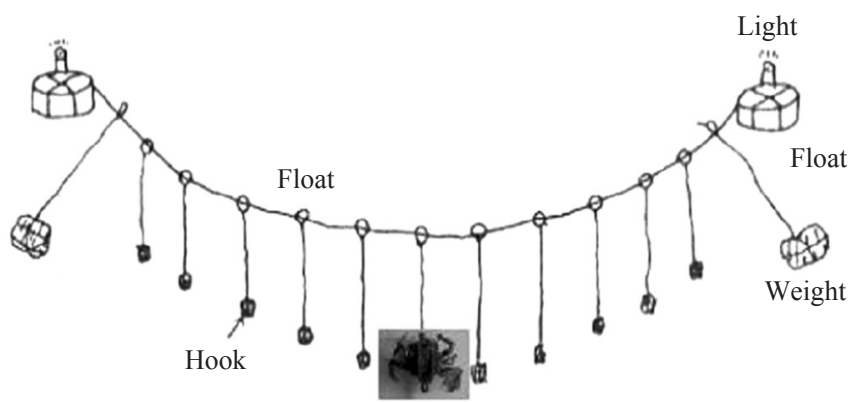

A: Lone line

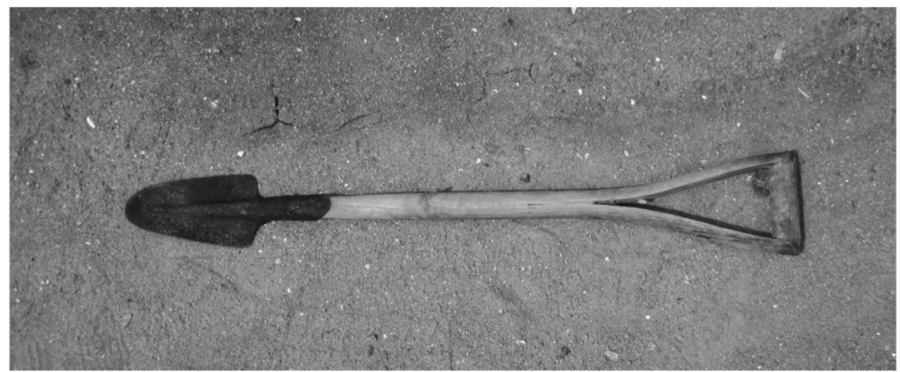

C: Shovel

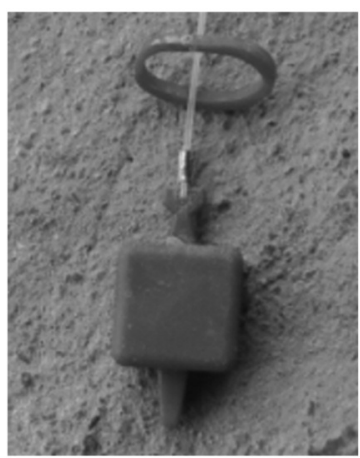

E: None hook type

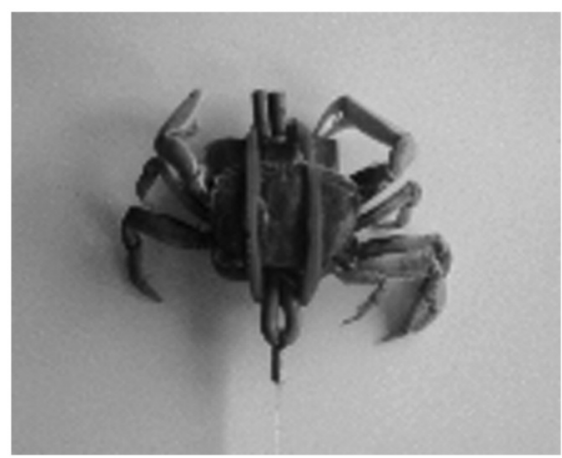

F: None hook type

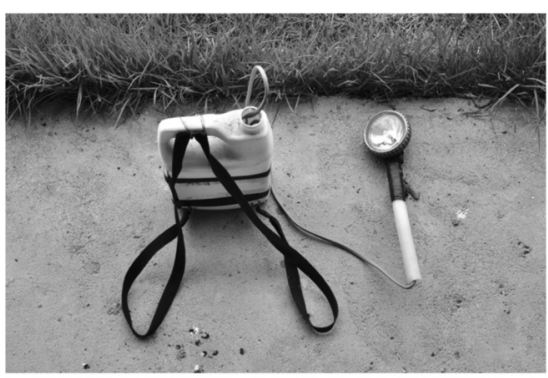

B: Torch light

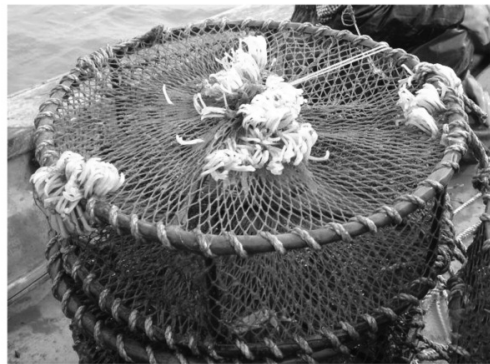

D: Trap

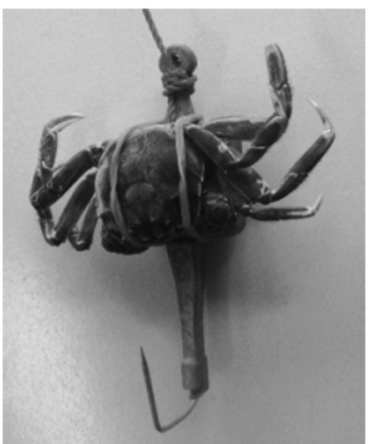

G: Hook type

Fig. 2. Several fishing gear and hook type of Octopus minor fishery in Tando bay, Korea.

을 사용하여 횃불을 만들어 사용 하였으나, 지금 은 Fig. 2의 C와 같은 배터리를 등에 지고 한손으 로 등을 잡고 다른 한손으로 아주 얕은 갯벌 위를 걸어가면서 물속에 보이는 낙지를 손으로 줍는 어업이다 그리고 통발어업은 미끼인 칠게 3-4 마리를 넣어 Fig. 2의 D와 같이 망목 $22 \mathrm{~mm}$ 인 원 통형 통발 100 개 내외를 모릿줄에 연결하여 썰물 때 나타나는 개웅 (갯골)에 투승하고 2-3일 후 양승하여 통발에든 낙지를 어획하는 어업이다.

\section{조업선 현황}

탄도만 내에서 조업하는 연승조업선은 $0.3-$ 1.0 톤 미만 크기로 선외기를 동력으로 사용하는 아주 소형어선으로 표 2과 같이 대부분이 $0.5-$ 1.0 톤 미만의 조업선이 $77.7 \%$ 를 차지하였으며, 연승어업에 종사하는 선박의 $93.3 \%$ 가 1 톤 미만 의 아주 작은 소형선인 것으로 나타났다. 조업선 에서 사용하는 동력은 2000년 이전까지는 주로 인력으로 노를 사용하였으나, 그 이후로는 선외 
Table 1. Size of long line vessel in Tando bay

\begin{tabular}{ccc}
\hline Size (ton) & No. of vessel & Rate $(\%)$ \\
\hline 0.49 below & 7 & 15.6 \\
$0.50-0.99$ & 35 & 77.7 \\
1.0 over & 3 & 6.7 \\
\hline
\end{tabular}

기가 보급되어 현재 모든 조업선에서 선외기를 사용하고 있으며, 빠른 속도를 요구하는 어장 이 동용 대형 선회기와 낮은 출력을 요구하는 조업 용 선외기를 각각 설치하여 사용하고 있다.

탄도만에서 가장 많은 낙지를 어획하는 연승 은 수심 2-3m 내외의 얕은 어장에서 어구(연 승) 1 바스켓을 투승하여 2-3분 정도 직각 방향 으로 $0.5 \mathrm{~m} / \mathrm{sec}$ 로 예인한 후 투승 역 방향으로 이 동하면서 주낙을 들어 올려 주낙에 낙지 부착 여 부를 확인하여 부착되지 않은 주낙은 다시 투승 하고, 낙지가 미끼를 섭이하기 위해 주낙에 부착 되어 있는 낚시에서는 낙지를 어획한 후 다시 주 낙을 투승하는 방법을 반복한다. 그렇지만 수심 이 비교적 깊은 $10 \mathrm{~m}$ 이상의 남해서부 연안해역 의 낙지 주낙은 Fig. 2의 G와 같이 낚시 밑에 바 늘이 있고 낚시에 칠게를 부착한 연승 20-30바 스켓을 투승한 후 1 시간 정도 대기 한 후에, 투승 한 전 주낙을 양승하면서 어획하는 어법이다. 이 와 같이 조업해역이나 수심에 따라 주낙의 형태 가 다른 것은 비교적 깊은 수심에서 조업할 때에 는 주낙에 바늘이 없으면 비교적 긴 시간 양승 중에 어획된 개체가 많이 탈락됨으로 이을 방지 하기 위해서 미끼 아래쪽에 바늘을 부착하여 조 업하는 것으로 판단된다. 그리고 탄도만의 조업 선은 Table 1 과 같이 1 톤 미만의 소형선이 대부 분인 것은 1 바스켓어구로서 주낙의 침적시간을 짧게 함으로써 투승과 양승을 짧은 시간에 반복 적으로 수행하여 조업의 효율성을 높이기 위한 것으로 생각된다. 그리고 낚시가 있는 주낙 2030 바스켓을 사용하는 해역에서는 5 톤급 조업선 에 5-6명의 선원이 어구를 양승과 동시에 선내 에서 다시 투승할 수 있도록 어구 정리에 종사한 다. 최근 탄도만에서는 주낙 자동 양승기가 개발

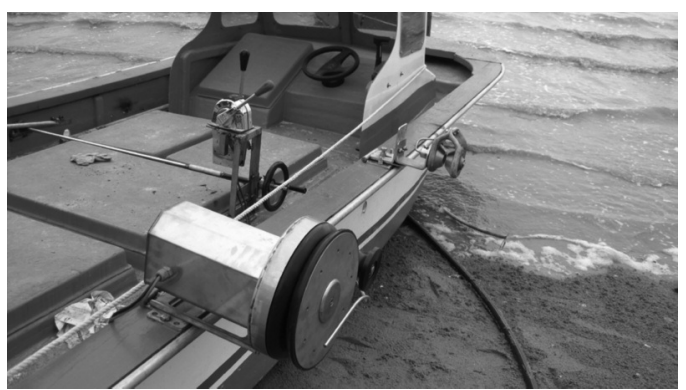

Fig. 3. Advanced long line of Octopus minor fishery in Tando bay, Korea.

보급되어 1 인 조업이 가능하여 한정된 탄도만 낙지 자원에 미치는 어획강도가 더 높아져 가고 있는 실정으로 이에 대한 대책이 필요하다 (Fig. 3). 탄도만에서 낙지 통발은 썰물 때 나타나는 개웅 (갯골)에 투승하고 2-3일 후에 양승하는 어구어법이지만, 서해남부지방 다른 해역의 낙 지 통발어업은 수심이 5-10m인 저질이 펄인 지 역에서는 당일 투승하고 다음날 양승하는 형태 로 어업이 이루어진다.

\section{탄도만 낙지 어업별 어획량}

탄도만 어업인 표본조사에서 추정된 낙지 어 획량은 Fig. 4와 같이 2003년 401톤을 정점으로 감소하기 시작하여 2005년 157톤으로 최저치를 보인 후 약간의 증가세를 보이지만, 이는 도수와 횃불어업이 조사에 추가되면서 어획량이 증가 한 것에 불과하며, 연승어업에서는 2003년 401

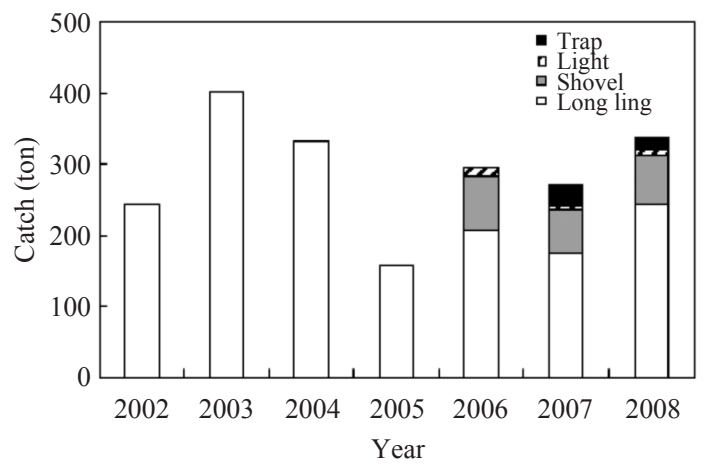

Fig. 4. Annual variations in catch of Octopus minor fishery in Tando bay, Korea. 
톤을 정점은 나타내고 그 이후 크게 감소한 뒤 안정적으로 증가하는 추세이며, 2008년에는 총 338 톤을 어획하였다. 어업별 차지하는 연승어업 이 $72.2 \%$ 로 244 톤, 도수어업이 $20.7 \%$ 로 70 톤, 통 발어업이 $5.3 \%$ 로 18 톤, 그리고 나머지 햇불어업 이 $1.8 \%$ 로 6 톤을 어획한 것으로 나타났다.

\section{연승어업의 척당 낙지어획량}

탄도만 낙지어획량의 $72.2 \%$ 를 차지하여 가장 많은 어획을 올리는 연승어업에서 1년간 1 척당 낙지어획량을 연도별로 살펴보면 Fig. 5와 같이 2003년 20,260마리, 2004년 16,860마리, 2005년 7,920마리, 2006년 6,920마리, 2007년 5,820마리, 2008년 8,095마리로 매년 감소한 후 약간 증가하 는 경향으로 나타났다. 또한 2006년과 2007년 월 별 1인당 연승 어획량변동에서 3-6월 (춘계)에 는 2,077마리를 어획하였고, 9월-12월(추계)에 서는 4,225 마리 어획한 것으로 나타났다. 이와 같은 결과는 춘계에 대량으로 부화한 어린 소형 개체가 성장하여 추계에 주로 어획되고, 추계에 소량 부화한 발생군이 춘계에 어획되는 것으로 추정된다.

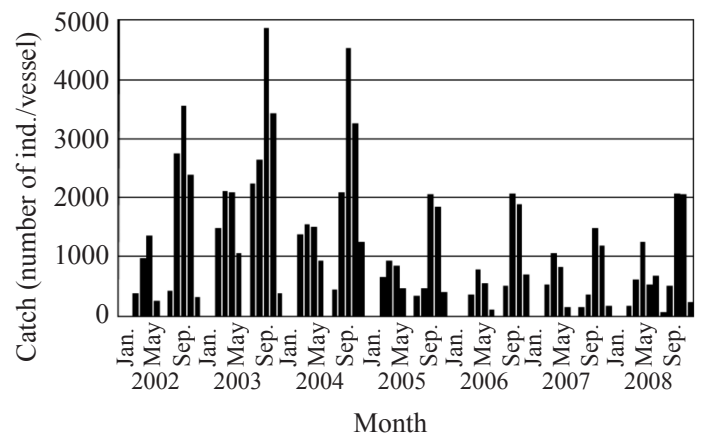

Fig. 5. Monthly variation of catch) by long line fishery in Tando bay, Korea.

\section{탄도만 낙지의 자원생물학적 특성 조사}

조사해역인 탄도만 내에서 어획된 낙지에 대 하여 자원생물학적 특성치를 파악하기 위하여 2006년 1,193마리, 2007년 1,354마리에 대한 생
물학적 조사를 실시하였다

\section{동장조성}

낙지의 월별 동장 조성은 Fig. 6과 같으며, 2006년도 동장조성에서는 7월에 평균 동장 $4.0 \mathrm{~cm}$ 로 가장 작았으며, 그 후 매월 평균 동장이 증가하여 11 월 $6.5 \mathrm{~cm}$ 까지 성장하는 경향을 보인 후, 12 월에 $5.3 \mathrm{~cm}$ 로 작은 개체가 출현하였다. 그 러나 이후 매월 평균 동장이 증가하여 2007년 5 월 평균 동장이 $8.0 \mathrm{~cm}$ 까지 성장하는 경향을 보 인 후, 2007 년 8 월에 평균 동장 $4.7 \mathrm{~cm}$ 의 소형개 체가 다시 출현하였고 10 월에 평균 동장 $6.4 \mathrm{~cm}$ 까지 성장하는 것으로 나타났다.

이와 같이 결과는 $\mathrm{Kim}$ and $\mathrm{Kim}$ (2006)이 보고 한 계절을 고려한 von Bertalanffy 성장식에서 0.3 년째 (109일째)의 동장은 $3.78 \mathrm{~cm}$ 로 추정되는 것으로 볼 때, 탄도만에서 7월과 8월에 새로 가 입하는 군은 춘계에 부화한 군으로 판단되며, 이

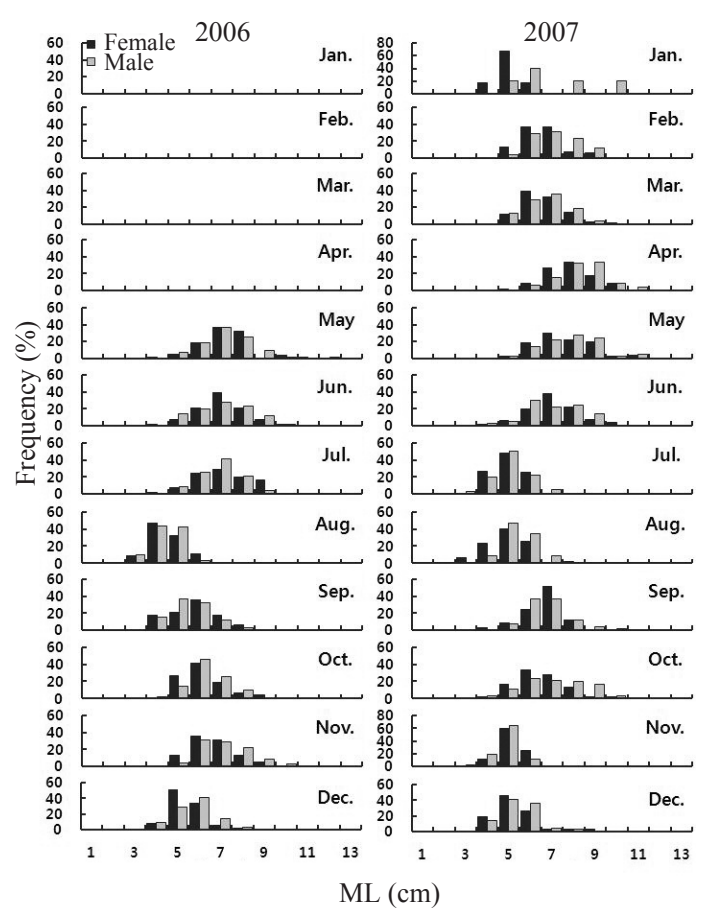

Fig. 6. Monthly size-frequency histograms for Octopus minor fishery in Tando bay, Korea. 
개체군이 점차 성장하여 추계 연승어업에 어획 되는 주 어획 개체군이 되고, 가을에 산란하여 12 월에 부화한 개체군은 춘계 연승어업의 주 어 획 개체군으로 판단된다.

\section{성 성숙}

낙지의 숙도지수는 Fig. 7과 같이 암컷의 월 평균 숙도지수는 6월에 $4.9(0.2-9.2$ 범위)였으 며, 5 월에는 $2.3(0.6-16.1$ 범위 $)$ 이고, 수컷의 월 평균 숙도지수는 6월에는 2.3 (0.4-32.4 범위), 5 월에는 1.5 (0.3-3.0 범위)이고, 추계인 10 월 $1.4(0.1-3.5$ 범위 $)$ 이후의 평균 숙도지수는 암 수 공히 0.3-1.3 범위인 것으로 나타났다. 6월 에 숙도지수가 최고치를 보인 후 점차 감소하고 다시 추계인 10 월에 다시 높게 나타난 후 서서 히 감소되는 이 현상은 수컷이 미리 교미를 위 해 암컷보다 좀 더 빨리 성숙해지는 웅성 성숙 현상을 나타내었다. 이와 같은 결과는 한국산 낙지의 선란에 관한 연구 (Yamamoto, 1942)에서 보고한 산란성기 5-6월 외에 늦은 가을에도 산 란한다고 보고한 것과 Kim and Kim (2006)이 보 고한 산란성기와 거의 일치하고, 본 연구에서도 10 월에 암컷의 숙도지수가 높게 나타난 것과 인 접 지역인 신안군 개펄에 서식하는 낙지를 대상 으로 한 연구 보고 $(\mathrm{Kim}, 2000)$ 에서는 $10-11$ 월 에도 성숙개체가 발견된 것으로 보고하고 있다. 따라서 낙지는 춘계 산란군과 추계 산란군이 있 는 것으로 판단된다.

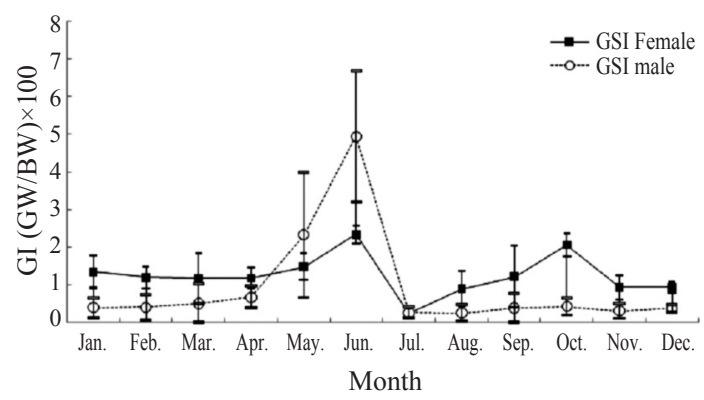

Fig. 7. Monthly changes in the GSI for Octopus minor fishery during Jan. 2007-Dec. 2007 in Tando bay, Korea.

\section{어업별 동장 조성}

탄도만에서 어획된 낙지의 어업별 동장 조성 은 Fig. 8과 같이 연중 어획되는 연승어업에서의 어획개체의 평균 동장은 $6.26 \mathrm{~cm}$, 도수어업 어획 개체의 것은 $5.82 \mathrm{~cm}$, 춘계에만 조업하는 통발어 업 어획개체의 것은 $8.09 \mathrm{~cm}$ 로 월등히 큰 것으로 나타났다. 이 결과를 Kim and Kim (2006)이 보고 한 생물학적 최소형 (군 성숙도 $50 \%$ 에 해당되는 크기) $7.06 \mathrm{~cm}$ 와 비교하며 연승어업과 도수어업 에서는 주로 미성숙개체를 어획하고 있으며, 춘 계에만 조업하는 통발에서는 작년에 부화된 성 숙개체만 어획하는 것으로 판단된다. 통발에서 대형 개체만 어획되는 것은 통발 망목 (규제 망 목 $22 \mathrm{~mm}$ )에 따른 영향으로 생각된다. 이와 같이 어획방법에 따라 낙지의 크기가 다른 것은 자원 을 관리하는 방법에서 산란에 참여하는 산란어 를 보호하고자 한다면 통발어업을 규제하여야 하고, 아직 성장 중인 미 성숙어를 보호하고자 한다면 연승어업과 도수어업을 규제하여야한 다. 따라서 탄도만 낙지자원을 지속적으로 이용 하기 위해서는 각 어업간의 충분한 협의와 자원 관리를 위한 다양한 방안이 필요하다.

\section{결 론}

본 연구에서는 탄도만 내 서식하는 낙지 자원 이용현황을 조사·분석하여 지역 연안 어업인 이 지속적이고 안정적인 어가 소득을 유지할 수

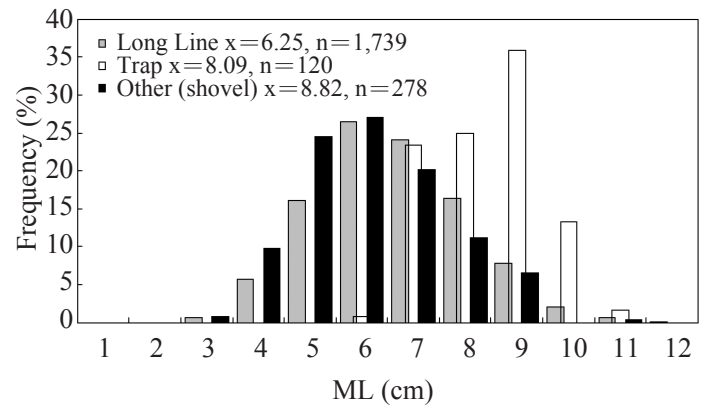

Fig. 8. Mantle length frequency distribution for Octopus minor fishery by long line, trap and Other (shovel) fishery in Tando bay, Korea. 
있는 방안을 모색하고자 하였다. 현재 탄도만에 서 낙지를 어획하기 위해서 연승어업 (301명)과 도수어업 (196명), 통발어업 (14명), 횃불어업 (40명)에서 많은 어업인이 종사하고 있다. 탄도 만에서 낙지 전체 어획량의 $70 \%$ 이상이 1 톤 미 만의 소형선에서 주낙 1 바스켓으로 반복 조업하 는 연승어업에서 어획되는 것으로 나타났다. 이 와 같이 매우 간단한 어로 장비로서 바늘이 없는 주낙어구 1 바스켓응 이용해 반복적으로 투승과 양승을 실시하여 1 일 조업이 가능하도록 된 것 은 탄도만 어장 특성에 알맞은 어구어법이 개발 되었기 때문이다. 그렇지만 최근에는 1 인 조업 이 가능하도록 자동 연승기가 개발 보급되고 있 는데, 이와 같은 자동화는 조업일수 증가와 불법 조업선의 증가에 따른 어획 강도의 증가로 이어 져 한정된 탄도만 낙지자원에 악 영향을 미칠 것 으로 생각되며 이에 따른 자원관리 방법이 제시 되어야 할 것이다. 탄도만에서 어획되는 낙지의 어업별 평균 동장은 연승어업 $6.26 \mathrm{~cm}$, 도수어업 $5.82 \mathrm{~cm}$, 통발어업 $8.09 \mathrm{~cm}$ 로 큰 차이를 나타내고 있다 이와 같은 차이는 어업의 특성에 따른 차이 로서 생물학적 최소형 (군 성숙도 $50 \%$ 에 해당되 는 크기) $7.06 \mathrm{~cm}$ 보다 평균 동장이 큰 통발어업 은 통발에 사용된 망목선택성에 의해 큰 개체가 어획된 것으로 판단되고, 생물학적 최소형 보다 평균 동장이 작은 연승어업은 연승어구에 낚시 바늘이 없어 양승 중 탈락하는 경우도 있을 수 있지만, 그것 보다는 부피가 큰 대형 개체는 양 승 중에 받는 유체 저항이 소형개체 보다 커므로 소형 개체보다 더 많이 탈락될 것으로 먼저 추정 할 수 있다. 그러나, 춘계에 탄도만 갯벌에서 부 화한 개체가 매월 성장하여 주 성어기인 10-11 월에 어획된 개체의 평균 동장이 $6.4 \mathrm{~cm}$ 인 것으 로 볼 때, 어획 주 대상 개체군이 미성숙 개체군 인 것으로 판단된다. 따라서 탄도만 낙지 자원관 리를 위해서는 먼저 산란 할 수 있는 친어 자원 을 보호할 것인지 아니면 미성숙 개체를 보호할 것인지 선택한 후 이에 맞추어서 자원관리 정책
을 추진해야 할 것으로 판단된다.

특히, 어로장비의 자동화에 따라 증가하는 어 획강도 감축을 위해서 어획강도 증가만큼 조업 선의 감척이 필요하고, 친어 자원 보호를 통한 자원관리 정책은 산란장을 보호육성하기 위한 보호수면 지정, 산란기에 금어기 설정, 통발어업 의 휴어보상제 실시 등이 필요하지만, 미성숙 개 체 보호를 통한 자원관리 정책은 포획금지 동장 설정과 같은 극단적인 조치보다는 어업인 스스 로 자원관리 필요성을 인식하고 각 어촌계 별로 어업인 스스로 순번을 정해 조업하는 순번제 조 업과 같은 자율적인 자원관리 제도가 추진될 수 있도록 지원하여야 할 것으로 생각된다.

\section{사 사}

본 연구는 국립수산과학원 (낙지 수산자원회 복을 위한 자원조사 평가, RP-2011-FR-010)의 지 원에 의해 수행되었습니다.

\section{참고문현}

Arguelles, J., P.G. Rodhouse, P. Villegas and G. Castilo, 2001. Age, growth and population structure of the jumbo flying squid Dosidicus gigas in Peruvian waters. Fish. Res., $5451-61$.

Chang, D.J. and D.A. KIM, 2003. Characteristics by Behaviour and Habits of the Common Octopus (Octopus minor) J. Kor. Fish. Soc., 36 (6), $735-$ 742.

Cortez, T.D,. A.F. Gonzalez and A. Guerra, 1999. Growth of octopus mimus (Cephalopoda, Octopodidae) in wild populations. Fish. Re., 42, 31 - 39.

Hernāndez-Garc̄a, V., J.L. Hernandez-Lopez and J.J. Castro-Hdez. 2002. On the reproduction of Octopus vulgaris off the coast of the Cannry Islands. Fish. Res., 57, 197-203.

Jung, J.M. and D.S. Kim, 2001. Influence of sea condition on catch fluctuation of long line for common octopus, octopus variddilis in the coastal waters of yosu (1). Bull. Kor. Soc. Fish. Tech., 37 (4), $321-325$. 
Kim, D.S., 2000. Development of breeding technique for Octopus minor. Case Reports on the Propagation of Maritime Affairs and Techniques, Korea, 5-24.

Kim, D.S. and J. Kim, 2006. Sexual Maturitu and growth Characteristics of Octopus minor. J. Kor. Fish. Soc., 39 (5), $410-418$.

Kim, S.T., J.Y. Kim, J.I. kim and S.D. Hwang, 2004. Growth and spawning of common octopus (Octopus minor) in southern coast of Korea. Proc. Symp. Fish. Sci. Soc., 2004, 362-363.

MIFAFF, 2008. Food, Agriculture, Forestry and Fisheries Statistical Yearbook. 1-453.

Moon, S.H., 1989. A study on the morphology and biology of Octopus minor in Kyoungi bay, Yellow sea. M.S. Thesis, Inha University, Korea, 1-49.
NFRDI, 2008. Fishing Gear of Korea. Hangul Graphics, $1-580$.

Tanaka, J. 1958. On the stock of Octopus vulgaris Lamarck on the east coast of Boso Peninsula, Japan. Bull. jap. Soc. sci. Fish., 24, 603-607.

Roper, C. F. E., M. J. Sweeney and C. E. Nauen, 1984. Cephalopods of the World: An annotated and illustrated catalogue of species of interest to fisheries. FAO Fisheries Synopsis, 125 (3), pp. 1-277.

Yamamoto, T., 1942. On the ecology of Octopus Variabilis typicus (Sasaki), with special reference to its breeding habit. Venus, 12, 9-12.

2010년 10월 18일 접수

2011년 2월 21일 1차 수정

2011년 2월 23일 2차 수정

2011년 2월 23일 수리 